\title{
Development of Bipolar Plate Stack Type Microbial Fuel Cells
}

\author{
Seung-Hun Shin. Youngjin Choi. ${ }^{\dagger}$ Sun-Hee Na, Seunho Jung., and Sunghyun Kim ${ }^{*}$ \\ Department of Chemisty and Depantment of Advanced Technology Fusion, Bio/Molecular Infomatics Cemer, \\ Konkak Lniversity, Seoul 143-701. Korea. ${ }^{*}$ E-mail. skimloolakonkuk ac.kr \\ ${ }^{+}$Department of Microbial Engineering and Deparment of Advanced Technology Fusion, Bio/Molecular Infomatics Cemer, \\ Konkuk University, Seoul 143-701, Korea. ${ }^{*}$ E-mail: shing@konkukackr \\ Received October 22, 2005
}

\begin{abstract}
Microbial tuel cells (MFC) stacked with bipolar plates have been constructed and their performance was tested. In this design, single fuel cell unit was connected in series by bipolar plates where an anode and a cathode were made in one graphite block. Two types of bipolar plate stacked MFCs were constructed. Both utilized the same glucose oxidation reaction catalyzed by Gram negative bacteria, Protews wulgaris as a biocatalyst in an anodic compartment, but two different cathodic reactions were employed: One with ferricyanide reduction and the other with oxygen reduction reactions. In both cases, the total voltage was the mathematical sum of individual fuel cells and no degradation in performance was found. Electricity from these MFCs was stored in a supercapacitor to drive external loads such as a motor and electric bulb.
\end{abstract}

Key Words : Microbial fuel cell, Bipolar plate, Stack cell, Thionin, Proteus vulgaris

\section{Introduction}

As one of biofuel cells, microbial fuel cells (MFCs) have attracted much attention as they can use various forms of biomass to generate electricity. Unlike enzyme fuel cells in which enzymes are used as biocatalysts, ${ }^{j-7}$ MFCs utilize living microorganisms to directly convert chemical energy to electricity. ${ }^{\phi-10}$ Anong many advantages of MFCs are environmental friendliness, a large selection of microorganisms, and abundance of fuels.

Although many different types of MFCs have appeared, ${ }^{11-17}$ the current design has not been changed much from a prototype since the basic concept of MFCs was introduced in the $60^{\circ} \mathrm{s}$. In this design, a single electrode plate is functioning either as an anode or as a cathode. This type of monopolar electrodes does not cause any problem for the purpose of demonstration or development of the MFCs. However, when it comes to the real application where the higher voltage is required to drive extemal electric devices, monopolar electrode systems may not be realized. Since a single MFC generate about $0.5 \mathrm{~V}$, several single cells should be connected in series to achieve higher voltage. A simple connection by conducting wire between an anode in one single cell and a cathode in the other single cell can cause unwanted problems such as i) non-uniform potential distribution on the electrode surface due to the point contact between an electrode plate and a connecting wire, ii) lower output voltage due to the potential drop occurring between an anode and a cathode, and iii) a large size of the whole cell. $^{18}$

In this paper, we have tried to overcome these problems by designing bipolar electrode plates. In this design, both anode and cathode exist in one plate. Since there are no contueting parts between anode and cathode, problems associated with non-uniform current distribution or voltage drop could be minimized. Also overall cell size can be made small simply by stacking the bipolar plates in series. Although bipolar plates electrodes have already been used in proton exchange membrane fuel cells ${ }^{17}$ where the bipolar plates mostly function as a reactant-supplying path and an electrical connection, actual electrochemical reactions can take place in our design. It is first time, to our knowledge, to apply this concept to MFCs. Here we have shown the basic concept of a bipolar stack type $\mathrm{MFC}$ and some preliminary results.

\section{Experimenral Section}

Preparation of microorganisms. $P$. vilgaris (ATCC 6059) was bought from KCTC (Korean Collection for Type Cultures) and maintained on a nutrient agar plate at $4{ }^{\circ} \mathrm{C}$. The experimental culture was aerobically grown in a nutrient badge containing $10 \mathrm{~g} \cdot \mathrm{L}^{-1}$ of $\mathrm{NaCl}, 10 \mathrm{~g} \cdot \mathrm{L}^{-1}$ of trypton, and $1.8 \mathrm{~g} \cdot \mathrm{L}^{-1}$ of glucose at 37 " $\mathrm{C}$. This culture was daily sub-cultured with $5 \%$ inoculums for three days, and the cells were harvested by centrifuging at $3000 \mathrm{~g}$ and then washed three times witl $0.05 \mathrm{M}$ phosphate buffer of $\mathrm{pH} 7.0$. This procedure was carried out at $4{ }^{\circ} \mathrm{C}$. The washed microorganisms were suspended in the phosphate buffer and the weight was adjusted to $10 \mathrm{mg} \cdot \mathrm{mL}^{-1}$ by dry mass. The cell concentration was detemined by UV-visible spectrophotometry and a cell colony counting method.

Chemicals. We employed an MFC system operated under the electron mediator which carried electrons from the microorganism to the anode. Thionin (Aldrich, USA) was used as the mediator since it gave the best performance anong molecules tested. ${ }^{19}$ Glucose (Aldrich) was used as a substrate although other carbohydrates could be utilized. These compounds were used without further purification. Other chemicals were of reagent grade or better. Solutions were prepared using deionized water of $18 \mathrm{MW} \cdot \mathrm{cm}$ obtained 


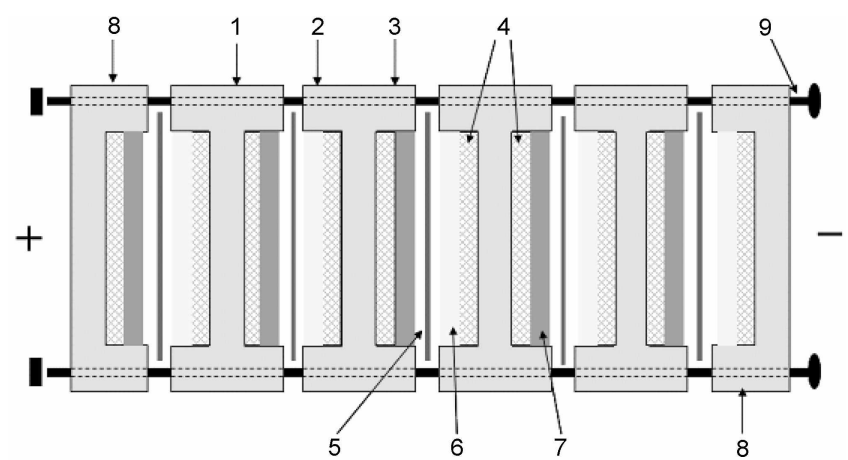

Figure 1. Schemalic diagram of a bipolar plate slacked microbial fuel cell. Five single eells are conneeted in series. Anodic compartment contains $P$. ithgaris, glucose and thionin. Ferricyanide reduction is used as a cathodic reaction. 1. Bipolar plate made of graphite, 2. anode, 3. callode, 4. RVC electrodes, 5. Nation membranc, 6. anolyte, 7. catholyte, 8. end plates, 9. serews. Volume of each compartment is $26 \mathrm{~mL}$.

from the ion exchange filter system (Younglin, Korea).

Bipolar stack fuel cell systems. Two types of bipolar stack MFCs have been constructed: One type used ferricyanide reduction as a cathodie reaction and the other, oxygen reduction. However, the anodic compartment in both designs comprised of $P$. vilgaris, substrate, and a mediator, ${ }^{20-22}$

Figure 1 shows the single eell-stacked MFC using bipolar plates. Fach bipolar plate was made of carbon block and machined into an $\mathrm{H}$-beam shape. It has two compartments at each side that can be used as an anodic and calhodic compartment. Reticulated vilreous carbons (45 pores per inch, E-Tech, LSA) were used as electrode material and firmly attached to the carbon plate for electrical connection. Between each bipolar plate was set a semi-permeable membrane. In this figure, five single cells are connected in series and yet only 6 plates are required including end plates. All the plates were strongly tightened by four long screws. Since anode and cathodes are in one bipolar plate, Ohmic drop and non-uniform current distribution could be mininized. An anodic reaction utilized electrons produced by glucose oxidation in $P$. vulgaris, which was transported to the anode by thionin. In the meantime, ferricyanide reduction was utilized at the cathode.

Another design in which the oxygen reduction reaction was employed at the cathode is shown in Figure 2. One face of a bipolar plate was grooved for the oxygen passage. Oxygen was catalytically reduced to water by the catalytic layer coated on the Nafion surface. The catalyst made of Ptembedded carbon nano powder (De Nora North America, CSA) was dispersed in $5 \%$ Nafion solution (Dupont, USA) and sprayed unto the Nafion membrane before subject to the hot pressing at $120{ }^{\circ} \mathrm{C}$. Oxygen gas was preheated by passing through the hot water before feeding to the cathode. This time two single cells were connected in series.

Electrical measurements. The discharge curve was recorded only after the open circuit voltage was stabilized with nitrogen gas flowing through the cell. Discharging was

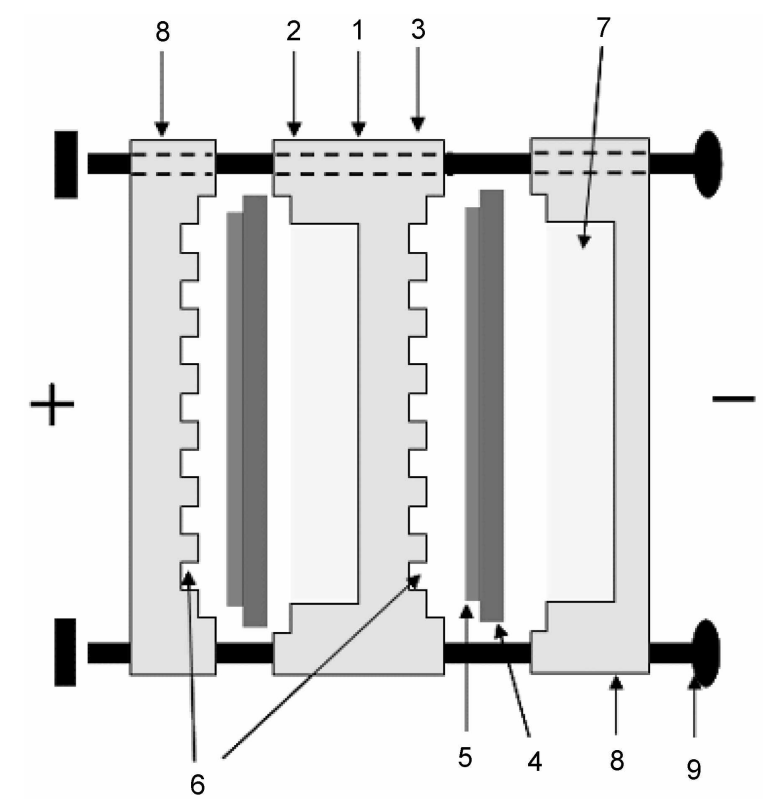

Figure 2, Schematic diagram of a bipolar plate stacked microbial fuel cell. Two single eells are connected in series. Anodic compartment (170 mL) contains $P$. whtgaris, glucose and thionin. Oxygen reduction takes place at a catalyst layer coated on Nafion lilm. 1. Bipolar plate made of graphite, 2, anode, 3. cathode, 4 . Nation membrane, 5. $\mathrm{Pt} / \mathrm{C}$ catalyst layer coated on Nation membrane, 6 . grooves for oxygen feeding, 7 . anolyte, 8 . end plates, 9. screws.

done by connecting an external resistor of various values between the anode and the cathode to obtain a polarization curve. The eell voltage with time was then recorded with a battery tester (Model WBCS-3000, Wonatech, Korea) connected to a personal computer. Current was simply calculated using the Ohm's law, $I=V_{\text {well }} / R_{\text {load. }}$. The power was calculated by multiplying voltage and current, $\mathrm{P}=\mathrm{V}_{\mathrm{c} \text { : ll }} \cdot \mathrm{I}$.

\section{Results and Discussion}

Electrochemical behaviors of thionin and ferricyanide. Figure 3 shows voltanmograms of thionin (panel A) and $\mathrm{Fe}(\mathrm{CN})_{6}{ }^{3-}$ (panel $\left.\mathrm{B}\right)$ in an fuel cell experimental condition. Thionin shows a reversible voltammetric behavior characteristic of adsorbed species. This certainly makes thionin a very promising electron mediator that can shuttle between microorganisms and the electrode. Note that due to the adsorption effect, current is not proportional to the concentration. Panel $\mathrm{B}$ shows that $\mathrm{Fe}(\mathrm{CN})_{6}{ }^{3-}$ reduction is diffusioncontrolled and easily reduced to $\mathrm{Fe}(\mathrm{CN})_{6}{ }^{4-}$, indicating that this species is an ideal cathodic fuel. Determined from the peak potential separation. the cell voltage of $c a .0 .5 \mathrm{~V}$ is expected.

Fuel cell performance test. Panel A in Figure 4 is the voltage output as a function of different external loads for the five single cells connected in series, in which ferricyanide reduction reaction was utilized at a cathode. The open circuit voltage of $2.5 \mathrm{~V}$ indicates that the single fuel cell generates $0.5 \mathrm{~V}$ which in turn confirms sur bipolar 

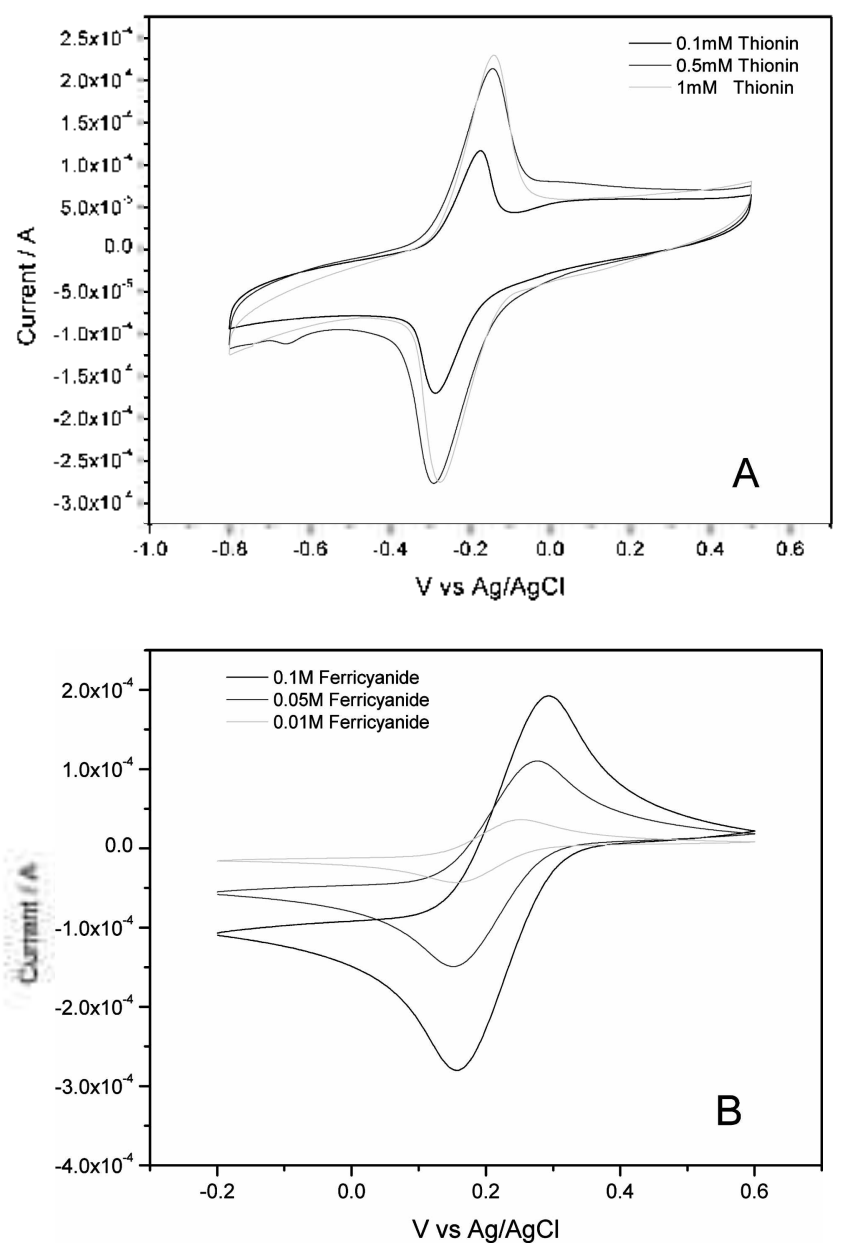

Figure 3. Cyclic voltammograms of thionin (panel $\Lambda$ ) and $\mathrm{Fe}(\mathrm{CN})_{k}^{3-}$ (pancl B) in pl 7 phosphate buffer at a carbon electrode. Both show the reversible redox behaviors.

stack type MFCs are working as expected. As the higher load was applied, the less output voltage was obtained. A new load was connected after the cell voltage was restored to the original value. However, once the higher load (smaller resistance) was applied, a full recovery was not achieved. The fact that physiological conditions of a microorganism are not the same as those in initial stage and the Nafion membrane function is slowly degraded by the thionin adsorption could be some of possible explanations.

Panel B is the plot of power density vs cell obtained from Panel A. Higher voltage resulted in lower the current. Fuel cell assessment can be made from the power by multiplying voltage and current. Maximum power of $0.13 \mathrm{~mW} \cdot \mathrm{cm}^{-2}$ in this case is regarded very low compared with those of inorganic fuel cell using oxygen and hydrogen as fuels. This number may not be taken seriously because the output power quite depends on the healthiness of microorganisms and the initial culture conditions.

Although the power density from the MFCs is quite low, MFCs can still find many applications in a real world. For the electric appliances consuming small power such as a small motor and electronic calculator, a single MFC can be used. In the case that the large power is needed, electricity
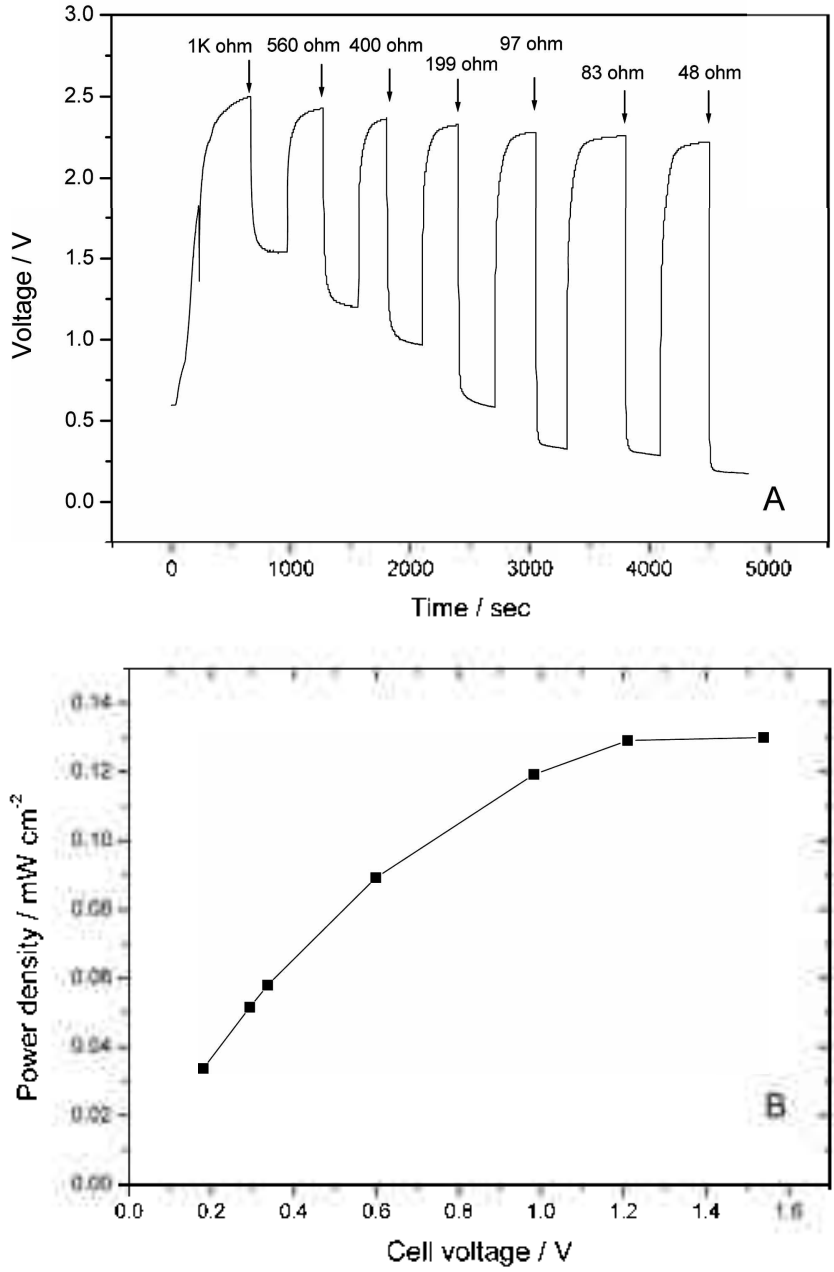

Figure 4. Voltage oulpul as a funclion of dillerent extemal loads for the five single cells stacked in series (pancl $A$ ) and corresponding plot of power density is cell voltage (panel B). Ferricyanide reduction reaction was utilized at a cathode. Volumes of anodic and calhodic comparments are $26 \mathrm{ml}$. Iach anodic compartment contains $2 \mathrm{~mL}$ of $P$. whorits suspended solution, 6 $\mathrm{mL}$ of $1 \mathrm{mM}$ thionin, $2 \mathrm{~mL}$ of $1 \mathrm{mM}$ glucose, and $16 \mathrm{~mL}$ of buffer solution.

from the MFCs can be stored in capacitors for the later use. We used a $1 \mathrm{~F}$ supercapacitor of $5.5 \mathrm{~V}$ voltage limit to store electrical energy. Figure 5A shows the output voltage variation as a function of time. After the induction period of ca. $200 \mathrm{~s}$, voltage slowly increased to $2.3 \mathrm{~V}$. Thus stored electricity could be used to lighten the electric bulb (Figure $5 \mathrm{~B})$.

Another example is the MFC using oxygen reduction reaction at a cathode. Using oxygen gas is advantageous over ferricyanide because oxygen can be supplied from air. However, since the incomplete reduction of oxygen to hydrogen peroxide may damage the cell and poison the cathode, the complete reduction to water is very important. We used Pt-dispersed carbon powder as a cathode material.

Panel $A$ in Figure 6 shows the discharging curve as a function of the external load. In this case two single cells were connected in series. The open circuit voltage of $c a .1 .2$ 

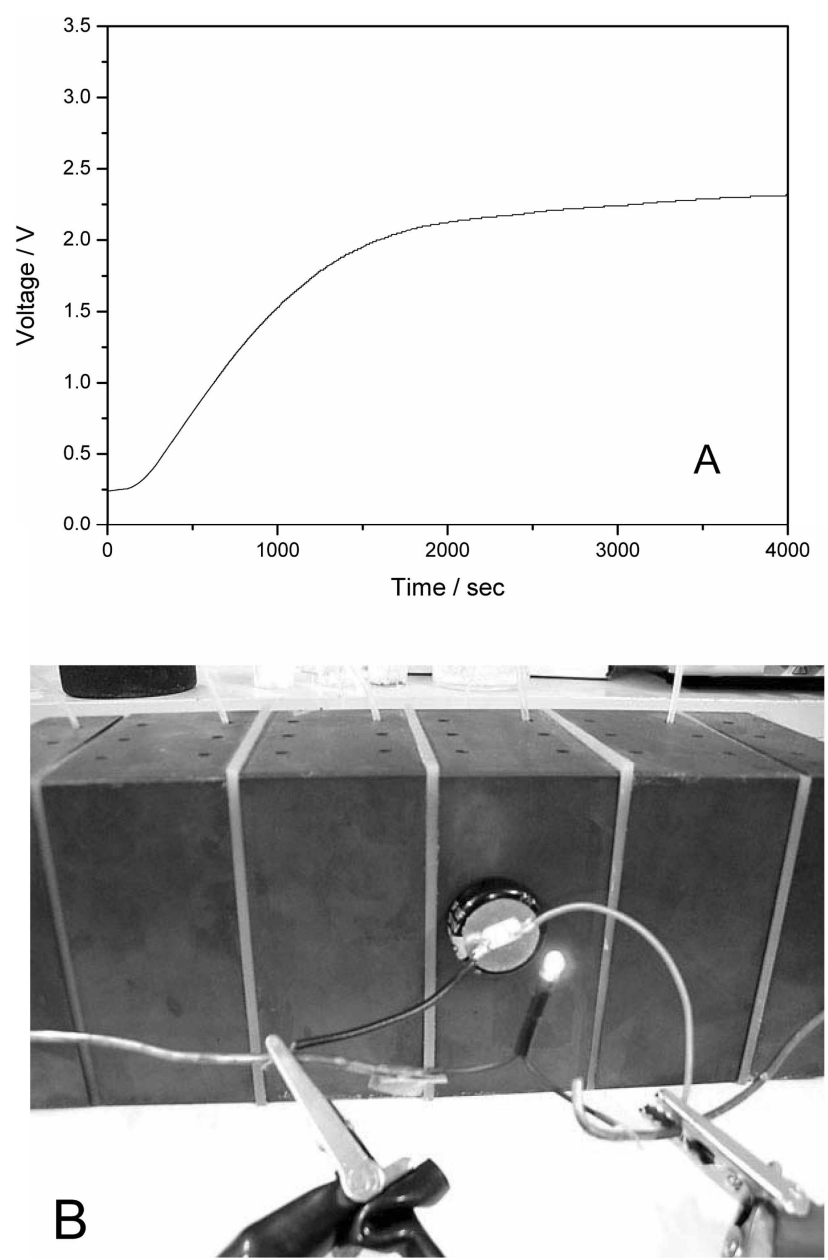

Figure 5. MFC output voltage change as a lunction of time (panel A) and the picture of powering of an electric bulb (panel I3) from electricity stored in a I 5 supercapacitor.

$\mathrm{V}$ corresponds to the sum of two single fuel cell voltages. The discharging pattern is similar to that of a MFC consisted of five single cells. Panel $B$ is the plot of power density vs
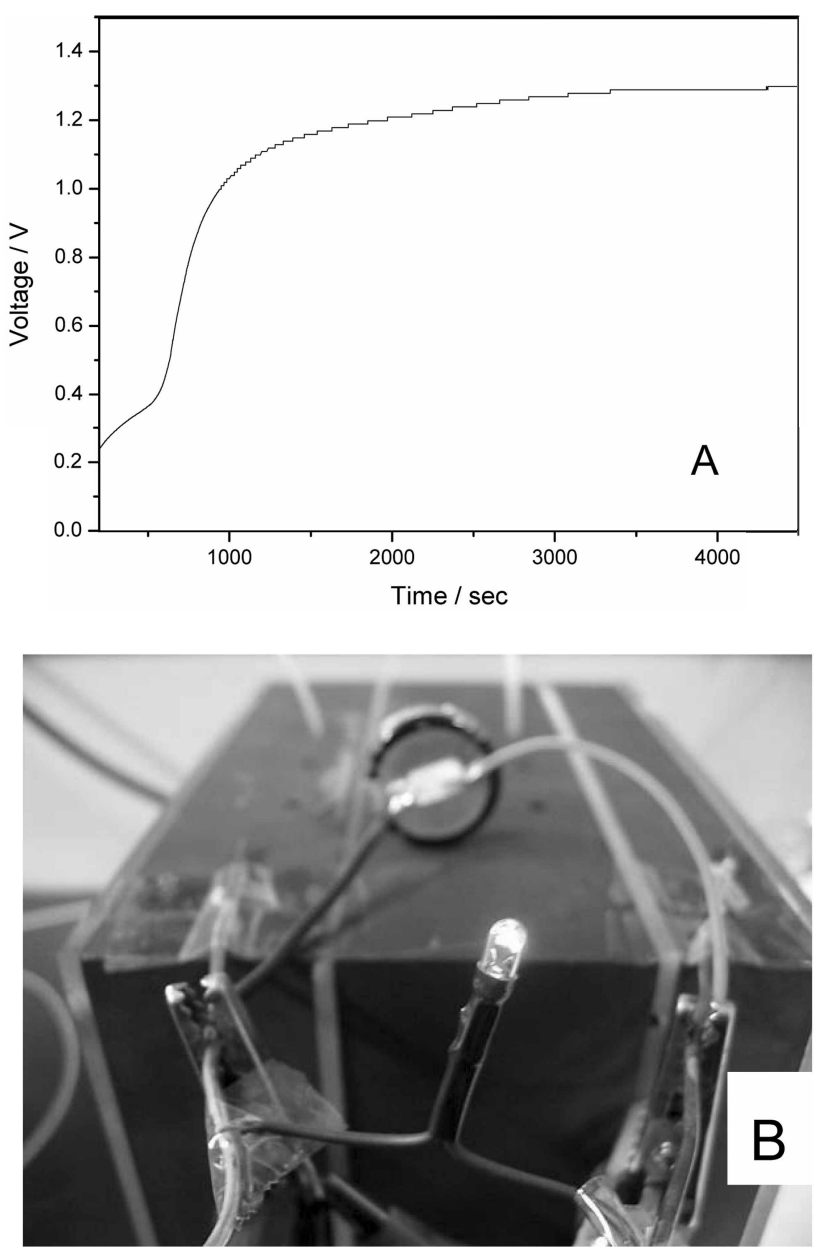

Figure 7. MFC output voltage change as a function of time (panel A) and the picture of powering of an electric bulb (panel 13) from electricity stored in a I F supercapacitor.

cell obtained from Panel A. Maximum power density of $0.023 \mathrm{~mW} \cdot \mathrm{cm}^{-2}$ was found to be lower than that in Figure 4. This is because we did not use RVC as an anode but rather

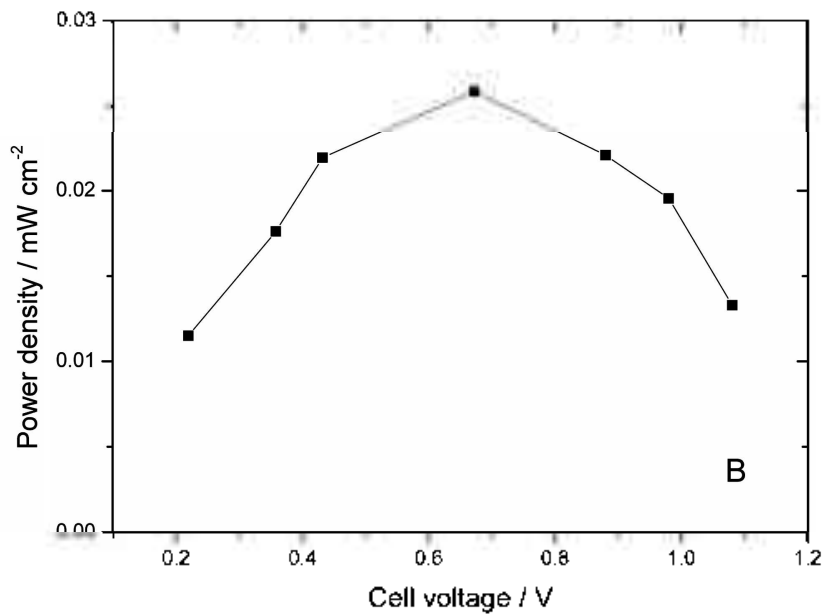

Figure 6. Voltage output as a function of diflerent external loads for the two single cells stacked in series. Oxygen reduction reaction was utilized at a cathode. Anodic volume is $150 \mathrm{~mL}$. Each anodic compartment contains $6 \mathrm{~mL}$ of $P$. valgaris suspended solution, $24 \mathrm{~mL}$ of $1 \mathrm{mM}$ thionin, $6 \mathrm{~mL}$ of I $\mathrm{mM}$ glucose, and $1 / 4 \mathrm{~mL}$ of bufter solution. 
used a graphite cell body as an electrode. A supercapacitor was also used to store energy generated from this MFC. Figure 7A shows the output voltage change as a function of time. After the induction period of $c a .500 \mathrm{~s}$, voltage slowly reached to $2.3 \mathrm{~V}$. Thus stored electricity was used to lighten the electric bulb (Figure $7 \mathrm{~B}$ ).

\section{Conclusions}

In this paper, we have shown the concept and some results of bipolar stack type MFCs. Contrary to the wire-connected MFC, we used bipolar plates functioning both as an anode and as a cathode to construct MFCs in which each single cell was contuected in series. The overall voltage was the mathematical sum of individual fuel cells and no decrease in performance was found. We constructed two MFCs: one with ferricyanide reduction and the other with oxygen reduction reaction at a cathode, but both with the same glucose oxidation reaction catalyzed by $P$. vilgaris at an anode. Electrical energy generated from both MFCs was stored in a supercapacitor to drive electrical devices such as a motor and an electric bulb. We hope that this type of MFCs can find applications in a real world.

Acknowledgement. This work was supported by Korea Santhak Foundation for the funancial support in the program year of 2004 .

\section{References}

1. Katz, E.; Willner, I. $J$, Am. Chem, Soc. 2003, 125, 6803.

2. Palmore, G. T. R.: Bertschy, H.; Bergens, S. H.; Whitesides, G M. $J$ Electroand. Chem. 1998, 443, 155.
3. Tsujimura, S.: Talsumi, H.: Ogawa, J.: Shimizu, S.: Kano, K.: Iheda. T. J. Electrownd, Chem. 2001, 496, 69.

4. Chen, T.; Barton, S. C.; Binyamin, G.; Gao, Z. Q.; Zhang. Y. C.; Kim. H. H.; Heller, A. J. Am. Chem. Soc. 2001, $123,8630$.

5. Mano, N.: Mao, F.: Heller, A. J. Am. Chem. Soc. 2002, 124, 12962.

6. Willner, I.: Kalz, E. Angen: Chem., hnt. Ed. 2000, 39, 1180.

7. Raitman, O. A.: Patolsky, F.; Katz, E.: Willner, I. Chem. Conmun. $2002,1936$.

8. Karube, I.; Matsunaga, T.; Tsunu, S.; Suzuki, S. Biotechnol. Bioeng. 1977, $19,1727$.

9. Delaney, G. M.: Bennetto, H. P.: Mason, J. R.; Roller, S. D.: Stirling, J. L.: Thurston, C. F. J. Chem. Tech. Biotechnol. 1984, $34 B, 13$.

10. Bemnetto, H. P.; Stirling, J. L.; Tanaka, K.; Vega, C. A. Biotechnol. Bioenc. 1983, 2.5. 559 .

1I. Davis, J. B.; Yartorough, H. F. Science 1962, 137,615.

12. Reimers, C. E.: Tender, L. M.; Fertig, S.; Wang, W. Emmon. Sci. Techol. 2001, 35, 192

13. Kim, H. J.; Park, H. S.; Hyun, M. S.; Chang, I. S.; Kiin, M.; Kiin, B. H. Enzyme Hicrob. Technol. 2002, 30, 14.5.

14. Wilkinson, S. Autoromons Robots. 2000, 9,99.

15. Stirling, J. L.: Bennetto, H. P.; Delaney, G. M.; Mason, J. R.: Roller, S. B.; Tanaka, K.; Thurston, C. F. Biochem. Soc. Trans. $1983, H, 45 \mathrm{I}$.

16. Allen, R. M.: Bennetlo, H. P. Appl. Biochem. Biotechnol. 1993, $39-40,27$

17. Choi, Y.; Jung, E.; Park, H.; Paik, S. R.; Jung, S.; Kiin, S. Bulll Korean Chem. Soc 2004, 25, 813.

18. Kordesch, K.: Simander, G. Fuel Cells and Their Appications: VCH: Weinheim, 1996.

19. Choi, Y.; Kim, N.: Kim, S.; Jung, \$. Bull. Korean Cheme Soc $2003,24,437$

20. Kim, N.; Choi, Y.; Jung, S.; Kim, S. Biotechrol, Bioeng. 2000, 70, 119.

21. Roller, S. D.; Bennetlo, H. P.; Delaney, G. M.; Mason, J. R.: Stirling, J. L.: Thurston, C. F. J. Chem. Tech. Biotechnol. 1984, $34 B, 3$.

22. Choi, Y.; Song, J.; Jung, S.; Kim, S. J. Aficrobial Biologr 2001, H, 863 . 